\title{
New methodologies for the preparation of carbon-11 labeled radiopharmaceuticals
}

\author{
Kenneth Dahl $^{1}$ (D) $\cdot$ Christer Halldin $^{1} \cdot$ Magnus Schou $^{1,2}$
}

Received: 6 October 2016/Accepted: 1 February 2017/Published online: 25 February 2017

(c) The Author(s) 2017. This article is published with open access at Springerlink.com

\begin{abstract}
Purpose This short review aims to cover the more recent and promising developments of carbon-11 $\left({ }^{11} \mathrm{C}\right)$ labeling radiochemistry and its utility in the production of novel radiopharmaceuticals, with special emphasis on methods that have the greatest potential to be translated for clinical positron emission tomography (PET) imaging.

Methods A survey of the literature was undertaken to identify articles focusing on methodological development in ${ }^{11} \mathrm{C}$ chemistry and their use within novel radiopharmaceutical preparation. However, since ${ }^{11} \mathrm{C}$-labeling chemistry is such a narrow field of research, no systematic literature search was therefore feasible. The survey was further restricted to a specific timeframe (2000-2016) and articles in English.

Results From the literature, it is clear that the majority of

${ }^{11} \mathrm{C}$-labeled radiopharmaceuticals prepared for clinical PET studies have been radiolabeled using the standard heteroatom methylation reaction. However, a number of methodologies have been developed in recent years, both from a technical and chemical point of view. Amongst these, two protocols may have the greatest potential to be widely adapted for the preparation of ${ }^{11} \mathrm{C}$-radiopharmaceuticals in a clinical setting. First, a novel method for the direct formation of ${ }^{11} \mathrm{C}$-labeled carbonyl groups, where
\end{abstract}

Kenneth Dahl

kenneth.dahl@ki.se

1 Department of Clinical Neuroscience, Centre for Psychiatric Research, Karolinska Hospital, Karolinska Institutet, 17176 Stockholm, Sweden

2 Department of Clinical Neuroscience, AstraZeneca Translational Science Centre, Karolinska Institutet, 17176 Stockholm, Sweden organic bases are utilized as $\left[{ }^{11} \mathrm{C}\right]$ carbon dioxide-fixation agents. The second method of clinical importance is a lowpressure ${ }^{11} \mathrm{C}$-carbonylation technique that utilizes solvable xenon gas to effectively transfer and react $\left[{ }^{11} \mathrm{C}\right]$ carbon monoxide in a sealed reaction vessel. Both methods appear to be general and provide simple paths to ${ }^{11} \mathrm{C}$-labeled products.

Conclusion Radiochemistry is the foundation of PET imaging which relies on the administration of a radiopharmaceutical. The demand for new radiopharmaceuticals for clinical PET imaging is increasing, and ${ }^{11} \mathrm{C}$-radiopharmaceuticals are especially important within clinical research and drug development. This review gives a comprehensive overview of the most noteworthy ${ }^{11} \mathrm{C}$-labeling methods with clinical relevance to the field of PET radiochemistry.

Keywords PET · Radiochemistry · Isotopic labeling · Carbon-11 - Radiopharmaceuticals

\section{Introduction}

Positron emission tomography (PET) is a highly sensitive imaging modality that can provide in vivo quantitative information of biological processes at a biochemical level [1]. PET relies upon the administration of a chemical probe, often called a radiopharmaceutical, that is labeled with a short-lived positron-emitting radionuclide [e.g. ${ }^{11} \mathrm{C}$ $\left(t_{1 / 2}=20.4 \mathrm{~min}\right)$ and $\left.{ }^{18} \mathrm{~F}\left(t_{1 / 2}=109.7 \mathrm{~min}\right)\right]$. Several PET radiopharmaceuticals have been developed for imaging applications, predominantly within oncology [2] and neuroscience [3,4]. The development of novel radiopharmaceuticals requires multiple considerations, where aspects like radionuclide selection, labeling position, metabolic 
stability, precursor synthesis, radiolabeling procedure, automation, quality control and regulatory affairs all have to be considered $[5,6]$.

Carbon-11 is one of the most useful radionuclides for PET chemistry, since its introduction into a biologically active molecule has minimal effects on the (bio)chemical properties of the compound [7, 8]. In addition, there is a vast literature on carbon-based chemistry that can be consulted in the development of radiosynthetic procedures with carbon-11. Moreover, the short half-life of ${ }^{11} \mathrm{C}$ allows for longitudinal in vivo studies with repeated injections in the same subject (patient or animal) and on the same experimental day. Although the advances in ${ }^{11} \mathrm{C}$ chemistry have enabled the preparation of a great number of radiolabeled molecules, there are still relatively few that have been applied for the direct preparation of novel radiopharmaceuticals for PET. The present review will provide an overview of the most recent and promising developments within carbon-11 chemistry since year 2000 .

\section{General considerations in radiopharmaceutical chemistry}

A few general comments are required to provide a context for a discussion of PET radiopharmaceutical production $[2,5]$. First of all, the radionuclides used in PET emit highenergy radiation and, therefore, the traditional hands-on manipulations used in synthetic chemistry are not feasible. Thus, in order to avoid unnecessary radiation exposure, radiolabeling is performed in fully automated and preprogrammed synthesis modules housed inside lead-shielded fume hoods (hot-cells). One could say that radiochemistry, in particular that with ${ }^{11} \mathrm{C}$, is a hybrid science between organic chemistry and engineering. Time is another factor of major importance in PET chemistry. A radiopharmaceutical used in PET is typically synthesized, purified, formulated and analyzed within a timeframe of roughly 2-3 physical half-lives of the employed radionuclide. For example, to obtain ${ }^{11} \mathrm{C}$-labeled radiopharmaceutical in optimal radiochemical yield (RCY), a compromise has to be made between the chemical yield and the radioactive decay. The chemical yield of a reaction is thus not as important as the obtained radioactivity of the target compound at end of synthesis. Furthermore, since only trace amount of the radiolabeling synthon is used in PET, the amount of the non-radioactive reagents is in large excess, which implies that the reaction follows pseudo firstorder kinetics. By consequence, small impurities in reagents or solvents may have a significant influence on the reaction outcome. The radiochemist has to further consider the specific activity (SA), which is a measure of the radioactivity per unit mass of the final radiolabeled compound. Since high SA is often required in neuroreceptor imaging studies to avoid saturation of the receptor system, the methods that are highlighted in this review are all non-carrier-added nature.

\section{Carbon-11 chemistry}

Carbon-11 is commonly generated via the ${ }^{14} \mathrm{~N}(\mathrm{p}, \alpha){ }^{11} \mathrm{C}$ nuclear reaction. The reaction is performed by high-energy proton bombardment of a cyclotron target containing nitrogen gas with small amounts a second gas. $\left[{ }^{11} \mathrm{C}\right]$ Carbon dioxide $\left({ }^{11} \mathrm{CO}_{2}\right)$ and $\left[{ }^{11} \mathrm{C}\right]$ methane $\left({ }^{11} \mathrm{CH}_{4}\right)$, are formed, when either small amounts oxygen or hydrogen are present in the cyclotron target. Sometimes, these simple primary precursors are used directly as labeling agents (e.g. ${ }^{11} \mathrm{CO}_{2}$ ), but more often they are converted via on-line synthetic pathways into more reactive species before being used in ${ }^{11} \mathrm{C}$-labeling reactions. However, several reactive ${ }^{11} \mathrm{C}$-labeled precursors have been developed over the years [8], but the ${ }^{11} \mathrm{C}$-precursors that will be discussed in this review are displayed and highlighted in Fig. 1.

\section{${ }^{11} \mathrm{C}$-methylation reaction}

By far, the most common method in modern carbon-11 chemistry is heteroatom methylation using the methylating agents $\left[{ }^{11} \mathrm{C}\right]$ methyl iodide $\left({ }^{11} \mathrm{CH}_{3} \mathrm{I}\right)[9,10]$ or $\left[{ }^{11} \mathrm{C}\right]$ methyl triflate $\left({ }^{11} \mathrm{CH}_{3} \mathrm{OTf}\right)[11,12]$. This reaction can either be performed using a traditional vial-based approach or alternatively using solid support ("on-cartridge" [13] or "in-loop" [14] methods), which is very convenient from an automation prospective. A majority of the ${ }^{11} \mathrm{C}$-labeled radiopharmaceuticals that are used on a regular basis, with a few exceptions, are thus produced by these two methylating agents. However, these methylating agents are sluggishly reactive towards arylamines. Especially difficult are substrates where the aryl group in a primary arylamine electron density has been further reduced by an electronwithdrawing group. In such situations, the more reactive methylating agent, ${ }^{11} \mathrm{CH}_{3} \mathrm{OTf}$, may even fail to react. However, Pike and co-workers presented a method that utilized inorganic bases (e.g. $\left.\mathrm{Li}_{2} \mathrm{O}\right)$ paired with $\mathrm{DMF}$ to permit methylation of a wide range of arylamines using ${ }^{11} \mathrm{CH}_{3} \mathrm{I}$ at room temperature [15]. Moreover, in a recent study, the research group of Billard described the application of ${ }^{11} \mathrm{CO}_{2}$ as a $\mathrm{C}_{1}$ building block for the catalytic methylation of amines [16]. Importantly, this one-pot approach eliminates the time-consuming preparation of the active methylating agent. The proposed mechanism is outlined in Table 1. In brief, an appropriate amine precursor, initially traps ${ }^{11} \mathrm{CO}_{2}$ to form complex $\mathbf{1}$, which is 
Fig. 1 Some transformations in carbon-11 radiochemistry. Those discussed in this review are highlighted in ovals

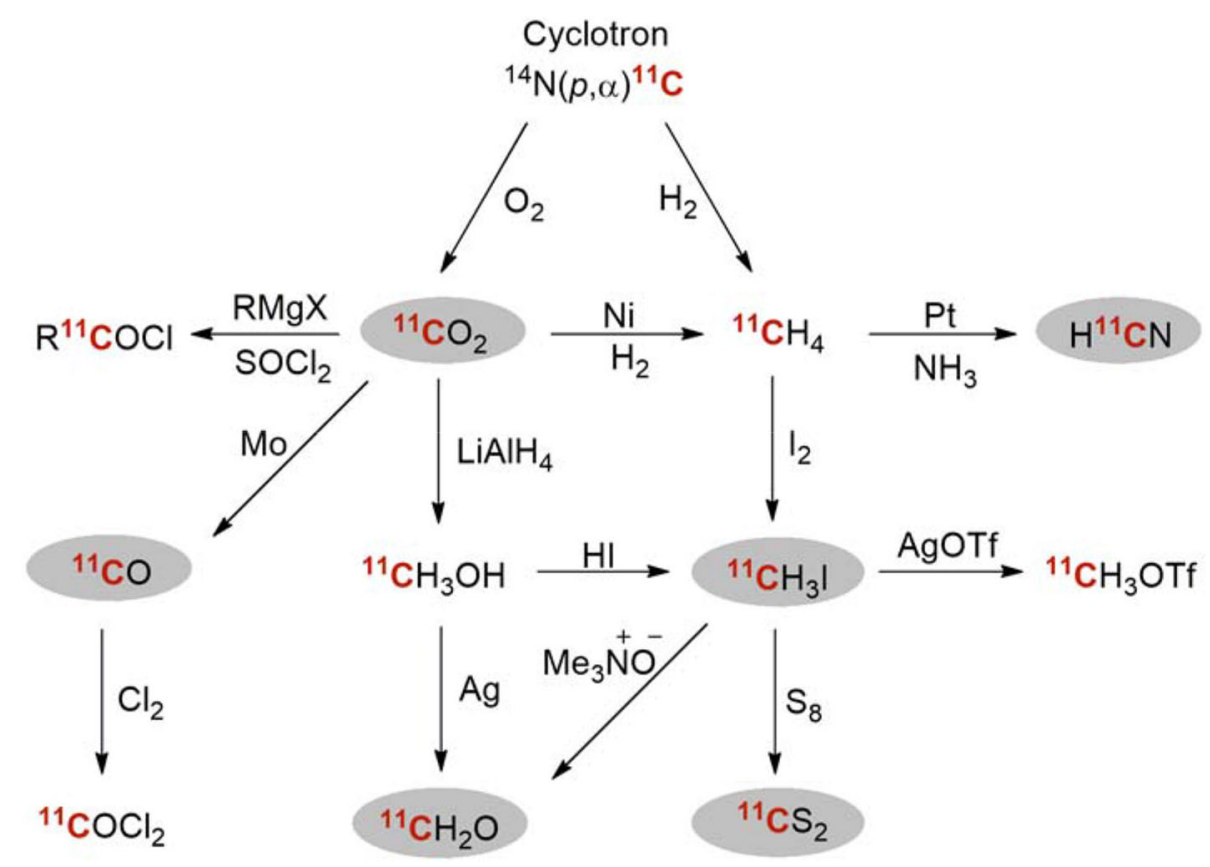

reduced in two-steps with $\mathrm{ZnCl}_{2} / \mathrm{Pr}$ and $\mathrm{PhSiH}_{3}$, to furnish the expected methylamine. It was realized that the ${ }^{11} \mathrm{CO}_{2}$ trapping was dependent on the basicity of the amine in use, varying between 65 and $80 \%$. A large number of substrates, including the well-established radioligand, $\left[{ }^{11} \mathrm{C}\right] \mathrm{PIB}$ [17], was obtained in acceptable yields (Table 1).

In recent years, the application of ${ }^{11} \mathrm{CH}_{3} \mathrm{I}$ in transitionmetal-mediated reactions has become more widespread for ${ }^{11} \mathrm{C}$-labeling of radiopharmaceuticals [18, 19]. Figure 2 shows a brief overview of compounds labeled via Pd-mediated ${ }^{11} \mathrm{C}$-methylation. Two radioligands for the serotonin transporter, [p-methyl- $\left.{ }^{11} \mathrm{C}\right]$ MADAM [20] and $\left[{ }^{11} \mathrm{C}\right] 5$ methyl-5-nitroquipazine [21], as well as a novel radioligand for the nicotinic acetylcholine receptor [22] (nAChRs) was methylated using the transition-metal-mediated reaction. $\left[{ }^{11} \mathrm{C}\right] \mathrm{A}-85,380$ displayed favorable in vivo properties for quantification of the nAChRs in living brain [23]. The nAChRs represents major neurotransmitter receptor responsible for various brain functions, and changes in the density of nAChRs have been reported in various neurodegenerative diseases, including Alzheimer's disease and Parkinson's disease [24]. Another example is the radiosynthesis of the $15 R$ - $\left[{ }^{11} \mathrm{C}\right] \mathrm{TIC}$ methyl ester, a prostacyclin receptor radioligand, which was the first radioligand approved for investigation in humans $[25,26]$. The same radioligand was later used to image variations in organic anion-transporting polypeptide function in the human hepatobiliary transport system [27].

Two of the most applied cross-coupling reactions in radiochemical synthesis today are the Stille and Suzuki reactions, where organotin and organoborane compounds function as starting materials, respectively, and ${ }^{11} \mathrm{CH}_{3} \mathrm{I}$ as a coupling partner. A wide variety of functional groups such as amino, hydroxyl, or carboxylate are tolerated in these reactions and protective groups are usually not required. One unfortunate drawback with Stille coupling is, however, the inherent toxicity of the organotin reagent. Because of the regulatory aspects associated with radiopharmaceuticals that are to be used in human subjects, the less toxic organoborate substrates are usually preferred. As an alternative route to ${ }^{11} \mathrm{C}$-methylated arenes, Kealey and coworkers describe a convenient two-step Pd-mediated crosscoupling of ${ }^{11} \mathrm{CH}_{3} \mathrm{I}$ with organozinc reagents (Scheme 1) [28]. The Nagishi-type reaction was used to synthesize a series of simple arenes in excellent yields. The same protocol was finally applied in the radiosynthesis of an mGluR5 radioligand, $\left[{ }^{11} \mathrm{C}\right] \mathrm{MPEP}$ [29]. Even though organozinc reagents are known to be moisture sensitive, it is much likely, that in the near future, Nagishi cross-coupling reaction will be considered a good alternative to the established protocols.

Enolates are a class of carbon centered nucleophiles that shortly may have a major importance in the radiopharmaceutical community. To generate an active enolate, a strong base, such as alkyl lithium or lithium diisopropylamide is typically needed. Using lithium bases to remove a $\alpha$-proton is not always adequate because of their moisture sensitivity. However, in 2010, two methods for the synthesis of ${ }^{11} \mathrm{C}$-labeled arylpropionic acid derivatives have been presented $[30,31]$. The rapid $\mathrm{sp}^{3}-\mathrm{sp}^{3}{ }^{11} \mathrm{C}$-methylation reaction relied on the formation of benzylic enolates, using either sodium hydride or tetrabutylammonium fluoride as base 
Table 1 Direct ${ }^{11} \mathrm{C}$-methylation of amines using ${ }^{11} \mathrm{CO}_{2}$

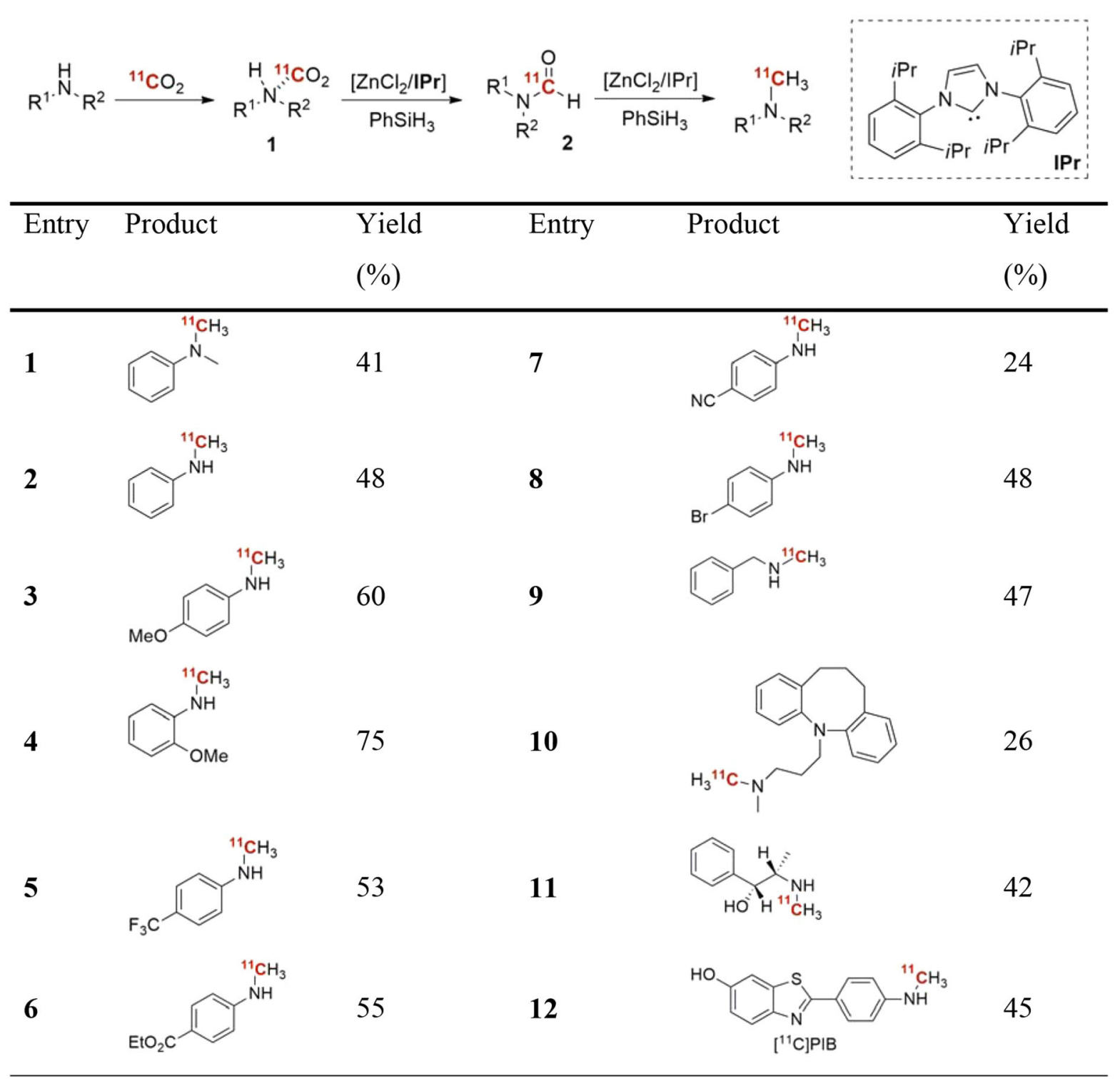

(Scheme 2). The reaction proceeds smoothly under mild conditions. However, until recently, the ${ }^{11} \mathrm{C}$-methylated product formed under these conditions was obtained in low enantiomeric purity. The use of chiral phase-transfer catalyst has enabled enantioselective synthesis of the amino acid, $\left[{ }^{11} \mathrm{C}\right] \mathrm{L}$-alanine, in high enantioselective purity [enantiomeric excess (ee) of 90\%] [32].

Moreover, this year, our group presented a novel (carbonyl)cobalt-mediated, and microwave-assisted, carbonylative protocol for the direct preparation of ${ }^{11} \mathrm{C}$ labeled aryl methyl ketones using ${ }^{11} \mathrm{CH}_{3} \mathrm{I}$ as the labeling agent [33]. The method uses $\mathrm{CO}_{2}(\mathrm{CO})_{8}$ as a combined aryl halide activator and carbon monoxide source for the carbonylation reaction. The method was used to label a set of functionalized (hetero)arenes with yields ranging from 22 to $63 \%$ (Scheme 3).

\section{${ }^{11} \mathrm{CO}_{2}$-fixation reaction}

$\left[{ }^{11} \mathrm{C}\right]$ Carbon dioxide is in itself a highly attractive starting material for radiolabeling, since it is produced directly in the cyclotron. However, due to low chemical reactivity, the direct incorporation of $\mathrm{CO}_{2}$ into organic molecules poses a significant challenge. High pressures, high temperatures or catalysts are commonly required to activate the molecule. 
Fig. 2 Radiopharmaceuticals labeled via metal-mediated ${ }^{11} \mathrm{C}$ methylation

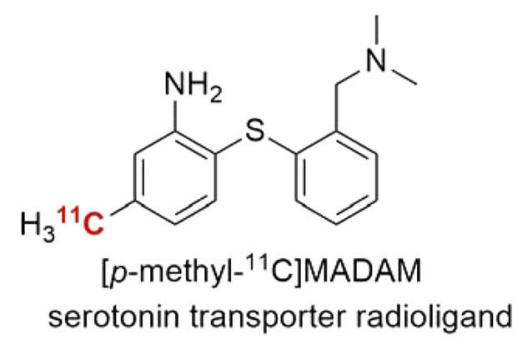<smiles>CC(=O)CCCCC1=C[C@H]2C[C@@H](O)[C@@H](/C=C/[C@@H](O)Cc3cccc([14CH3])c3)[C@H]2C1</smiles>

15R-[11 C $]$ TIC

Prostacyclin receptor radioligand<smiles>Cc1cccc(C#Cc2ccccc2)n1</smiles><smiles>Cc1c([N+](=O)[O-])ccc2nc(N3CCNCC3)ccc12</smiles>

$\left[{ }^{11} \mathrm{C}\right] 5$-methyl-6-nitroquipazine serotonin transporter radioligand<smiles>Cc1cncc(OCC2CCN2)c1</smiles>

$\left[{ }^{11} \mathrm{C}\right] \mathrm{A}-85380$

Nicotinic acetylcholine receptor radioligand
Scheme 1 Pd-mediated crosscoupling of ${ }^{11} \mathrm{CH}_{3} \mathrm{I}$ with organozinc reagent

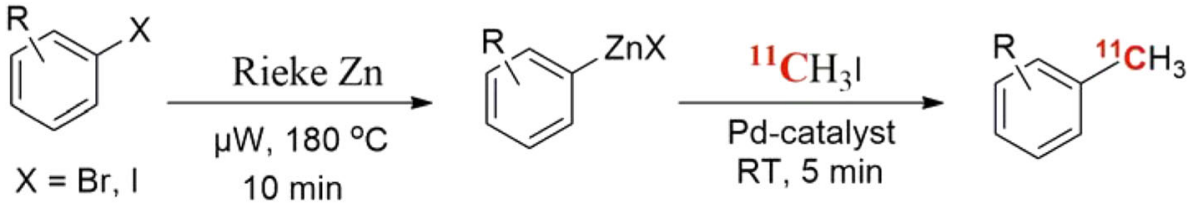<smiles>COC(=O)Cc1ccccc1</smiles>

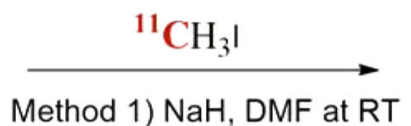<smiles>COC(=O)C(C)(C)c1ccccc1</smiles><smiles>CC(C(=O)O)c1ccc(C#N)cc1</smiles>
Method 2) TBAF, THF at RT

Scheme 2 Synthesis of ${ }^{11} \mathrm{C}$-labeled 2-arylpropionic acids and their methyl esters

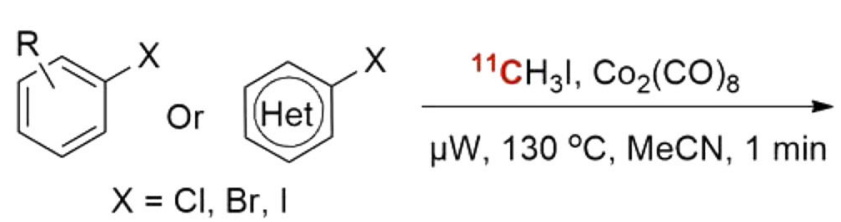<smiles>CC(=O)c1ccccc1</smiles>

Or<smiles>[14CH3]C(=O)c1ccccc1</smiles>

Scheme 3 The formation of aryl methyl ketones via direct ${ }^{11} \mathrm{C}$-acetylation with ${ }^{11} \mathrm{CH}_{3} \mathrm{I}$

The traditional method for ${ }^{11} \mathrm{CO}_{2}$ "fixation" is the Grignard reaction, which involves the conversion of alkyl or aryl magnesium halides to $\left[{ }^{11} \mathrm{C}\right]$ carboxylic acids. However,
Grignard reagents require great care and the rigorous exclusion of atmospheric moisture and $\mathrm{CO}_{2}$ during storage and manipulation. To overcome these limitations, two 


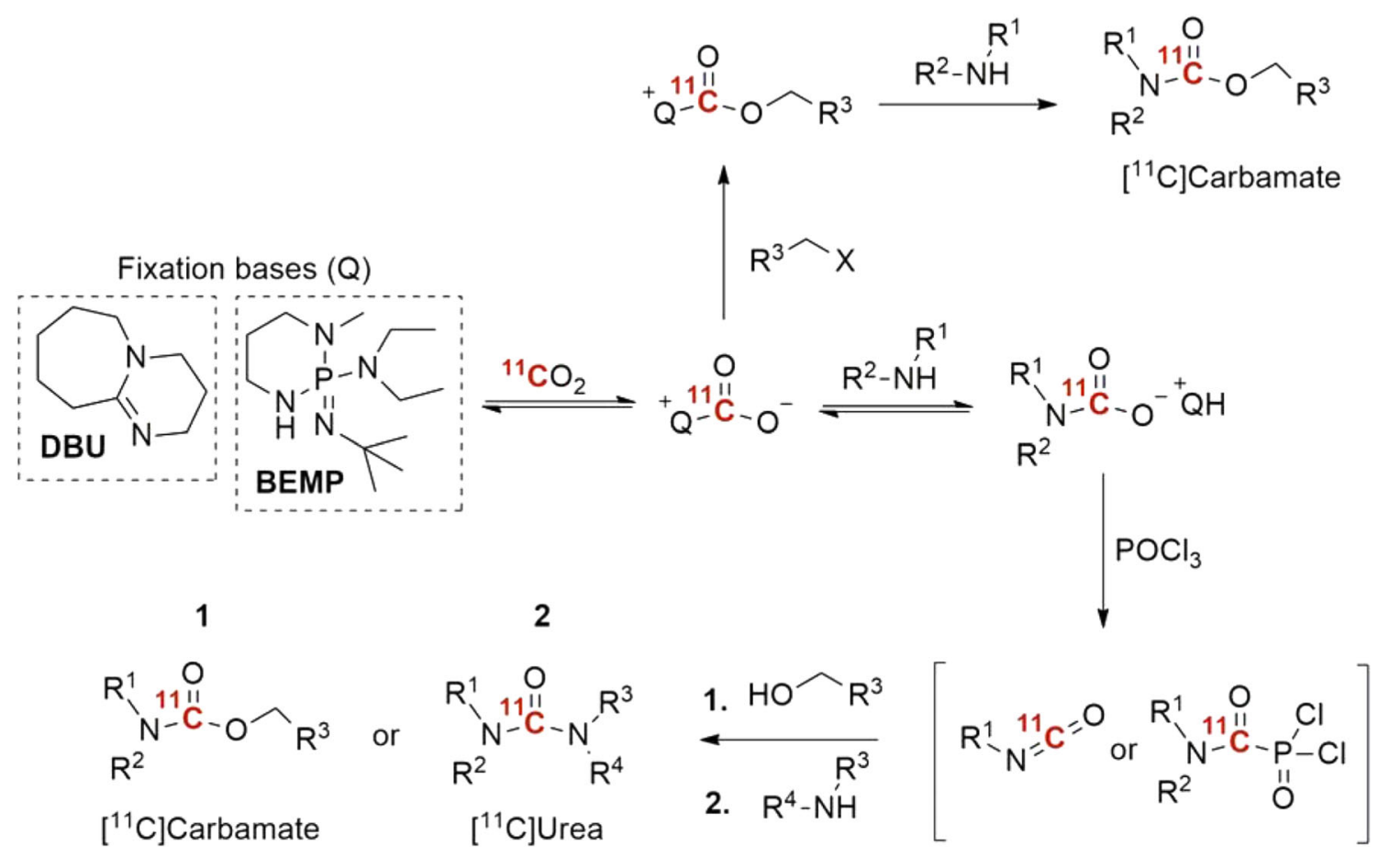

Scheme 4 Proposed pathways of ${ }^{11} \mathrm{C}$-labeled urea and carbamates via ${ }^{11} \mathrm{CO}_{2}$-fixation chemistry [37]

independent research groups presented what arguably can be viewed as the most ground-breaking advance in the field of carbon-11 chemistry since ${ }^{11} \mathrm{CH}_{3} \mathrm{I}$ was introduced in the early 1970s. The innovative method, that was inspired by the recent advances in "green chemistry" and reported in 2009, uses sub-milligram amounts of precursor compound, reacts at low temperature (typically room temperature), for 1-3 min reaction time and does not require advanced technical equipment [34, 35]. To overcome the low reactivity of $\mathrm{CO}_{2}$, organic amines such as DBU or BEMP act as organomediators by activating $\mathrm{CO}_{2}$ prior to the covalent bond formation $[36,37]$. The first report on ${ }^{11} \mathrm{CO}_{2}$ fixation was on the synthesis of ${ }^{11} \mathrm{C}$-labeled carbamates. However, the scope of the method was later broadened to include $\left[{ }^{11} \mathrm{C}\right]$ ureas and $\left[{ }^{11} \mathrm{C}\right]$ oxazolidinones (Scheme 4) [38], via the formation of an ${ }^{11} \mathrm{C}$-labeled isocyanate or carbamoyl anhydride intermediate. A number of drug-like molecules have been prepared using this methodology in recent years (2009-2016, see Fig. 3). These includes, the carbonyl analogue radioligand of $\left[{ }^{11} \mathrm{C}\right.$-methyl $] \mathrm{AR}-\mathrm{A} 014418$, a compound developed for imaging of synthase kinase $3 \beta$ (GSK-3 $\beta$ ) [39]. However, unfortunately, the in vivo evaluations of AR-A014418 revealed an undesirably low brain uptake [40]. Moreover, two potent and irreversible fatty acid amide hydrolase (FAAH) inhibitors, $\left[{ }^{11} \mathrm{C}\right] \mathrm{PF}-$ 04457845 [41] and [ $\left.{ }^{11} \mathrm{C}\right] \mathrm{CURB}$ [42], have also been prepared. The latter, $\left[{ }^{11} \mathrm{C}\right] \mathrm{CURB}$, have recently been translated to a clinical setting for reginal quantification of FAAH activity in human brain [43]. Furthermore, the reversible monoamine oxidase $\mathrm{B}$ (MAO-B) radioligand, $\left[{ }^{11} \mathrm{C}\right] \mathrm{SL} 25.1188$, previously prepared using the technical demanding $\left[{ }^{11} \mathrm{C}\right]$ phosgene approach, was radiolabeled in high yield via ${ }^{11} \mathrm{CO}_{2}$-fixation [44, 45]. This radioligand was recently translated for human PET imaging [46].

Later, on a related subject, Dheere and co-workers presented a further refinement to the methodology to obtain $\left[{ }^{11} \mathrm{C}\right]$ ureas from less reactive amines, such as anilines [47, 48]. Once again, DBU was used to trap ${ }^{11} \mathrm{CO}_{2}$ in solution, but in this case, it was shown that treatment of the carbamate anion intermediate (5) with Mitsunobu reagents, $\mathrm{DBAD}$ and $\mathrm{PBu}_{3}$, provided the corresponding asymmetric ureas in high radiochemical conversion (Scheme 5).

In the interest of expanding the scope of ${ }^{11} \mathrm{CO}_{2}$ as a feedstock in radiochemical synthesis, copper-mediated approaches to carboxylic acids and their derivatives have been described $[49,50]$. In the most recent example, the combination of $\mathrm{Cu}(\mathrm{I})$ with boronic esters enabled $\mathrm{CO}_{2}$ activation in the presence of a soluble fluoride additive and an organic base. In this reaction, the use of TMEDA was found to be crucial for obtaining high radiochemical yields, an observation likely explained by its dual action as both a trapping agent for ${ }^{11} \mathrm{CO}_{2}$ and a ligand for the copper catalyst. A variety of functional groups were tolerated under optimized conditions, and the generated ${ }^{11} \mathrm{C}$-carboxylic acids could be further converted into either amines or esters, as exemplified in the one-pot two-step preparation of a candidate radioligand for the oxytocin receptor. 
<smiles>COC[C@H]1CN(c2noc3cc(OCCCC(F)(F)F)ccc23)C(=O)O1</smiles>

monoamine oxidase- $\mathrm{B}$ radioligand<smiles>CS(=O)(=O)O[C@H](I)[CH]C(=O)N1CCC(=Cc2cccc(Oc3ccc(C(F)(F)F)cn3)c2)CC1</smiles>

Fatty acid amide hydrolase radioligand<smiles>O=C(Nc1ccccc1)Oc1ccc(O)c(-c2ccccc2)c1</smiles>

\section{$\left[{ }^{11} \mathrm{C}\right] \mathrm{CURB}$}

Fatty acid amide hydrolase radioligand<smiles>COc1ccc(CNC(=O)Nc2ncc([N+](=O)[O-])s2)cc1</smiles><smiles>C=C(c1ccc([14C](=O)O)cc1)c1cc2c(cc1C)C(C)(C)CCC2(C)C</smiles>

$\left[{ }^{11} \mathrm{C}\right]$ Bexarotene

Fatty acid amide hydrolase radioligand<smiles>O=C(c1ccc(-c2ccccc2)cc1)N(CC1CC1)CC1CCCO1</smiles>

\section{Oxytocin recepror radioligand}

Fig. 3 Radiopharmaceuticals labeled via ${ }^{11} \mathrm{CO}_{2}$-fixation chemistry

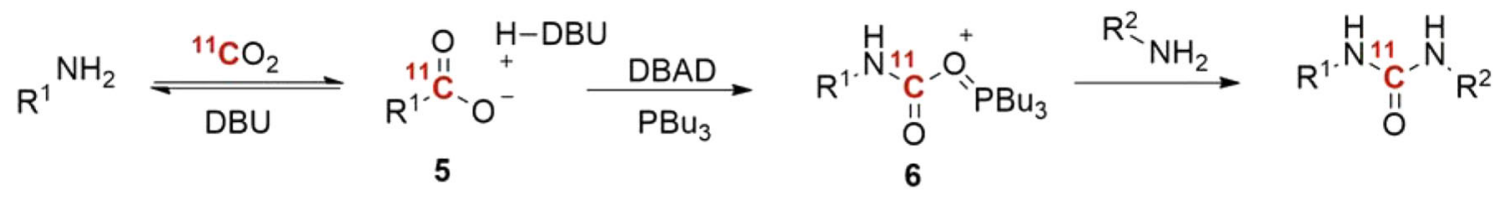

Scheme 5 Proposed pathway for ${ }^{11} \mathrm{C}$-labeled urea formation using Mitsunobu reagents

\section{Carbonylation reactions using ${ }^{11} \mathrm{CO}$}

$\left[{ }^{11} \mathrm{C}\right]$ Carbon monoxide $\left({ }^{11} \mathrm{CO}\right)$ has many attractive features as a synthon for PET radiochemistry, including its facile production [51, 52] and high versatility in transition-metal-mediated carbonylation reactions [53-56]. The widespread use of ${ }^{11} \mathrm{CO}$ in radiosynthetic chemistry was until recently hampered by its poor reactivity. Several solutions have been introduced to overcome the above shortcomings, both from a technical and chemical point of view [57-60]. A breakthrough was reported in 1999, where Kihlberg and co-workers introduced a method wherein ${ }^{11} \mathrm{CO}$ was allowed to react in a small autoclave under high solvent pressure ( $>350$ Bar) [61]. The high- pressure reactor methodology exhibited nearly quantitative ${ }^{11} \mathrm{CO}$ trapping efficiency and high radiochemical yield. Even though this method has exemplified the importance of ${ }^{11} \mathrm{CO}$ as a labeling precursor it has not gained broad adoption in the PET radiochemistry community. This can partly be attributed to the overall complexity of the autoclave system and the relatively high level of service needed to maintain the system operational. Moreover, the repeated use of an integrated stainless steel reactor may infer issues related to transition metal build up over time, which is problematic in reaction development and system validation.

In recent years, the development of low-pressure techniques has been in focus. In 2012, an efficient protocol was 
Fig. 4 Radiopharmaceuticals labeled via ${ }^{11} \mathrm{CO}$ low-pressure techniques<smiles>C=CC(=O)NCCCC[C@H](CN1CCN(c2cccc(C)n2)CC1)NC(=O)Cc1ccccc1</smiles>

TG2 radioligand<smiles>O=C(N1CCCCC1)C12CC3CC(CC(C3)C1)C2</smiles>

$11 \beta-H S D 1$ radioligand<smiles>CCNC(=O)c1ccc([C@@H]2CC2C(=O)N2CCN(C3CCC3)CC2)cc1</smiles>

Histamine type-3 receptor radioligand<smiles>O=C1NC(=O)C(c2ccccc2)(c2ccccc2)N1</smiles>

$\left[{ }^{11} \mathrm{C}\right]$ phenytoin

P-glycoprotein radioligand<smiles>CCN1CCC[C@H]1CNC(=O)c1c(O)c(Cl)cc(Cl)c1OC</smiles>

$\left[{ }^{11} \mathrm{C}\right.$-carbony $]$ Raclopride Dopamine $D_{2}$ receptor radioligand<smiles>CCCCOC(=O)NS(=O)(=O)c1sc(CC(C)C)cc1-c1ccc(Cn2ccnc2)cc1</smiles>

Angiotensin II subtype 2 receptor radioligand reported by Eriksson and co-workers, in which ${ }^{11} \mathrm{C}$-carbonylation reactions were achieved without the need for high-pressure equipment [62]. The high solubility of xenon gas in organic solvents was exploited as an effective way of transferring ${ }^{11} \mathrm{CO}$ into a sealed standard disposable reaction vial $(1 \mathrm{ml})$ without significant pressure increase. The utility of the method was exemplified by ${ }^{11} \mathrm{C}$-labeling of amides, ureas, and esters. The use of disposable glass reaction vessels eliminates carry over issues associated with the high-pressure autoclave system, thus simplifying the transition to clinical applications. Recently, three reports were published using the same ${ }^{11} \mathrm{CO}$ transfer protocol (Fig. 4). Windhorst et al. produced three ${ }^{11} \mathrm{C}$-labeled acryl amide radioligands for in vivo PET imaging of the tissue transglutaminase (TG2) enzyme [63]. Moreover, with the "xenon-method" as the synthesis platform, the Uppsalagroup presented two novel approaches to ${ }^{11} \mathrm{C}$-carbonyl labeled compounds. Firstly, a new multicomponent reaction for ${ }^{11} \mathrm{C}$-labeling of sulfonyl carbamates was described [64]. The method was further applied as a synthetic tool for the in vivo evaluation of an angiotensin II receptor subtype $2\left(\mathrm{AT}_{2} \mathrm{R}\right)$ agonist. Secondly, a method to access ${ }^{11} \mathrm{C}$-labeled alkyl amides via a thermally-initiated radical reductive dehalogenative approach [65]. One of the restrictions of transition-metal-mediated reactions is the competing $\beta$ hydride elimination of the resulting metal-substrate intermediate, which precludes the use of alkyl electrophiles containing $\beta$-hydrogen. This unfortunate competing reaction is non-excitant for radical pathways. A series of unactivated alkyl iodides was successfully converted into the corresponding alkyl amide in good RCY, including the radiosynthesis of an 11 $\beta$-HSD1 inhibitor.

Specific Pd-complexes have also been shown to trap ${ }^{11} \mathrm{CO}$ at ambient pressure and without the need for any high-pressure equipment [66, 67]. XantPhos, a hindered bidentate phosphine ligand, in combination with palladium ( $\mu$-cinnamyl) chloride dimer were found to be excellent for promoting ${ }^{11} \mathrm{C}$-carbonylation reactions. Notably, in this study it was discovered that, depending on the palladiumligand complex in use, different ${ }^{11} \mathrm{CO}$ trapping efficiency 
Table 2 Ligand effect in ${ }^{11} \mathrm{C}$-aminocarbonylation reaction at ambient pressure

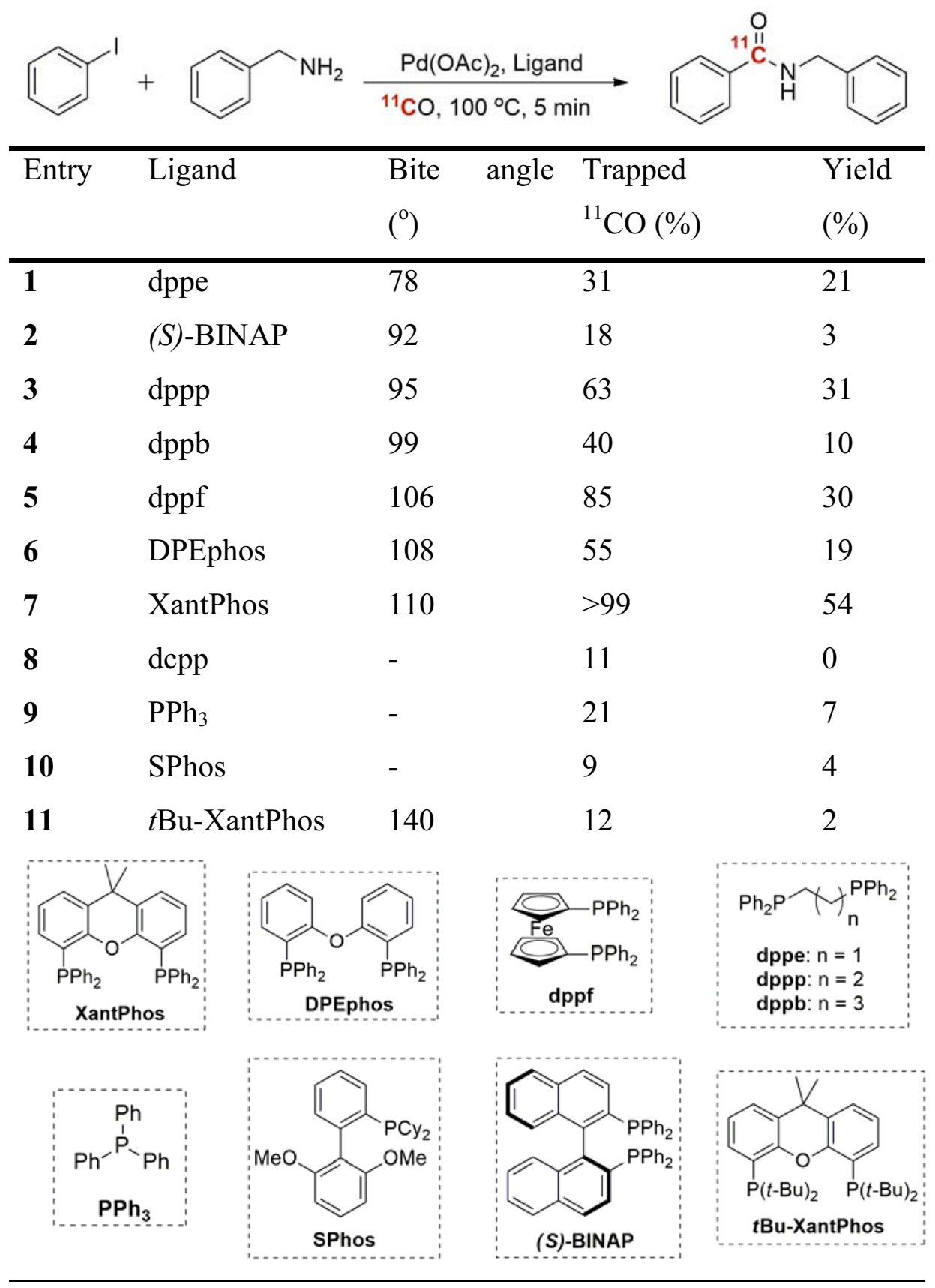

was observed (Table 2). The reaction proceeds smoothly at close to atmospheric pressure with aryl halides or triflates as substrates using simple disposable glass vials. This method was recently also applied in the preparation of well-known $\mathrm{D}_{2}$ radioligand, $\left[{ }^{11} \mathrm{C}\right]$ raclopride, but with the carbon-11 labeled in the more metabolically stable carbonyl group (Fig. 4) [68]. Interestingly, in a direct comparison between $\left(\left[{ }^{11} \mathrm{C}\right]\right.$ methyl)raclopride (produced using the standard ${ }^{11} \mathrm{C}$-methylation approach) and $\left(\left[{ }^{11} \mathrm{C}\right]\right.$ carbonyl $)$ raclopride, both radioligands showed similar in vivo properties with regards to quantitative outcome measurements, radiometabolite formation and protein binding.

The protocol was further improved by Andersen and coworkers, where pre-generated $(\operatorname{Aryl}) \operatorname{Pd}(\mathrm{I}) \mathrm{L}_{\mathrm{n}}$ oxidative addition complexes were utilized as precursors for the following ${ }^{11} \mathrm{C}$-carbonylation reaction [69]. This is exemplified in the preparation of $\left[{ }^{11} \mathrm{C}\right.$ - carbonyl $]$ raclopride in 


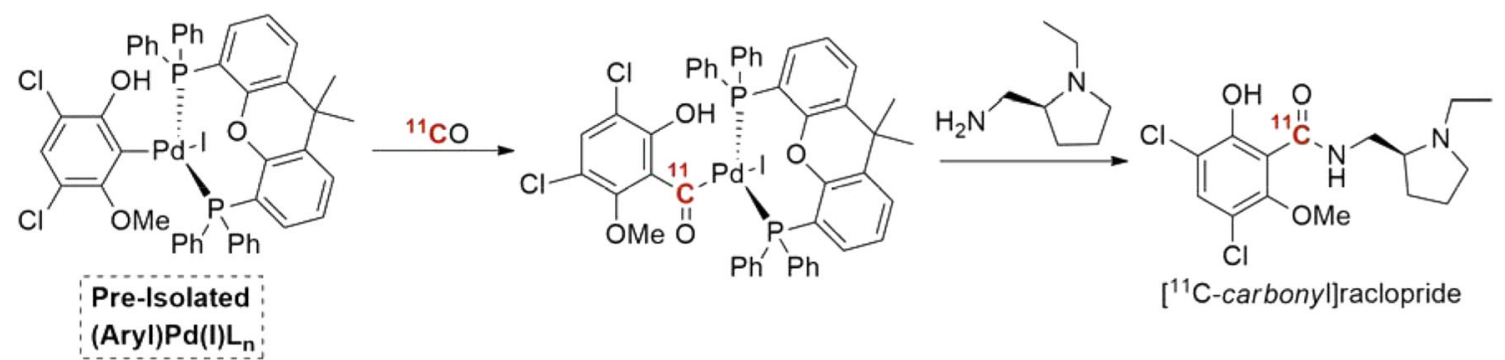

Scheme 6 Labeling based on pre-isolated (Aryl)Pd(I) $\mathrm{L}_{\mathrm{n}}$ complexes with ${ }^{11} \mathrm{CO}$

Table 3 Nickel-mediated ${ }^{11} \mathrm{C}$-aminocarbonylation of iodoalkyl compounds

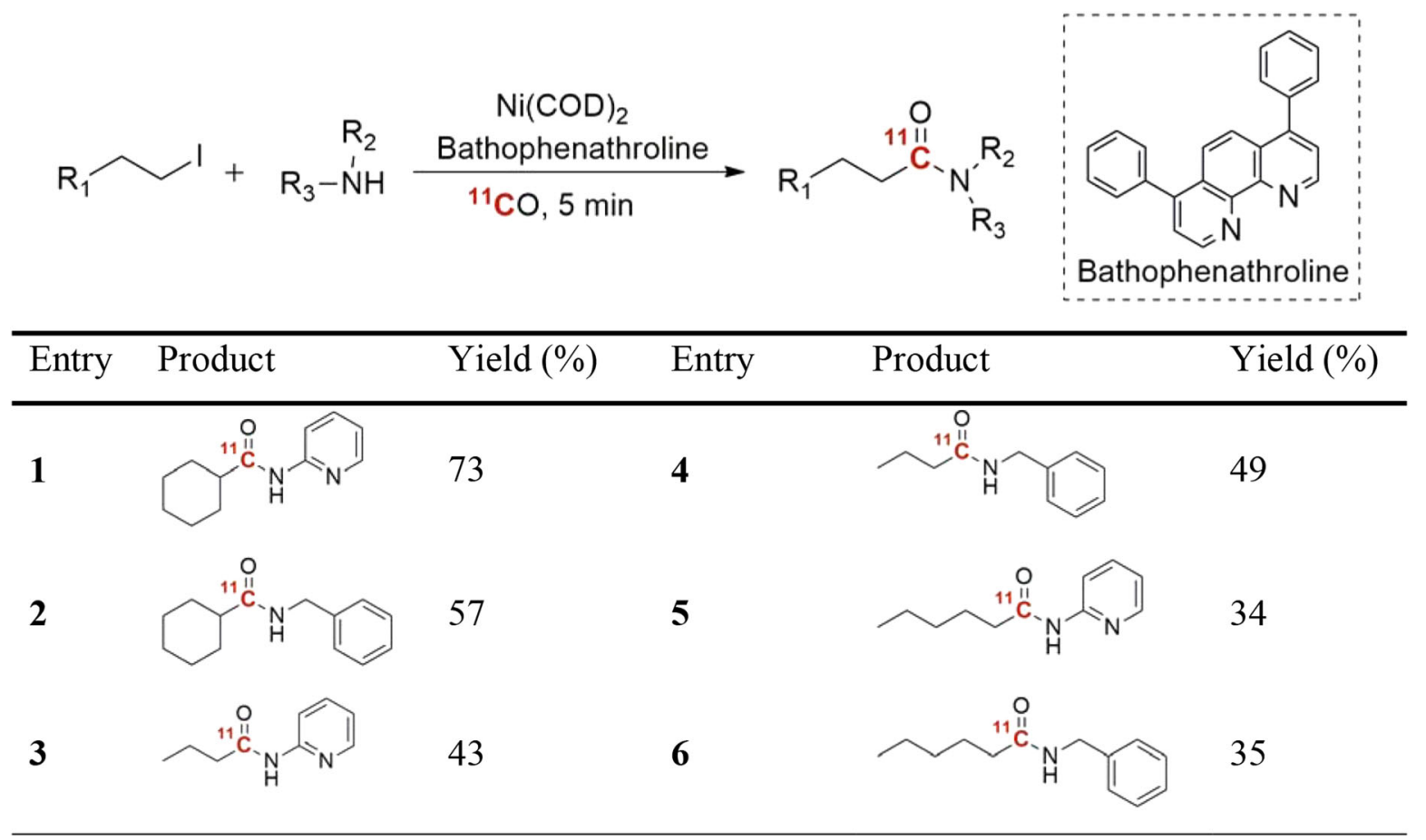

Scheme 6. The isolated complexes, (Aryl) $\mathrm{Pd}(\mathrm{I}) \mathrm{L}_{\mathrm{n}}$, have already undergone the potentially challenging oxidative addition step before their employment in carbonylative ${ }^{11} \mathrm{C}$-labeling. In this case, Pd-XantPhos complexes appeared to be among the most reactive precursors, although, electron-deficient aryl precursors demanded Pd$\mathrm{P}(t-\mathrm{Bu})_{3}$ to prevent aryl scrambling with phosphine ligand. The simplicity of these low-pressure techniques, and especially the "xenon-method" delivery protocol, may offer a potential for being widely adopted in radiopharmaceutical research and development.

As mentioned previously, one restriction with transitionmetal-mediated reactions is the competing $\beta$-hydride elimination. However, in contrast to $\mathrm{Pd}$ or Rh catalyst, nickel has been known to suppress the $\beta$-hydride elimination reaction. In the light of this, Rahman and co-workers recently reported the first successful use of nickel-mediated carbonylative cross-coupling of non-activated alkyl iodides using ${ }^{11} \mathrm{CO}$ at ambient pressure [70]. The best conditions identified in this study made use of a nickel(0) precatalyst, $\mathrm{Ni}(\mathrm{COD})_{2}$, in the presence of bathophenantroline as ligand (Table 3). Six model compounds were successfully radiolabeled in acceptable to good yields. However, more data is required to establish if the method is suitable of preparing more complex molecules.

\section{Other recent advances in carbon-11 chemistry}

Hydrogen cyanide is well established as a versatile precursor in PET radiopharmaceutical chemistry [71-73], and its involvement in metal-mediated cyanation of aryl 
Table 4 Pd-mediated radiosynthesis of $\left[{ }^{11} \mathrm{C}\right]$ aryl nitriles

$$
\left[(\mathrm{LPd})_{n}(\mathrm{COD})\right] \underset{\mathrm{RT}, 30 \mathrm{~min}}{\stackrel{(\mathrm{Het}) \mathrm{Ar}-\mathrm{Br}}{\longrightarrow}}[\underset{\text { (Het)Ar }}{\stackrel{\mathrm{Pd}}{\mathrm{Br}}}] \underset{\mathrm{RT}, 1 \mathrm{~min}}{\stackrel{\mathrm{H}^{11} \mathrm{CN}}{\longrightarrow}}(\mathrm{Het}) \mathrm{Ar}-\mathrm{CN}
$$

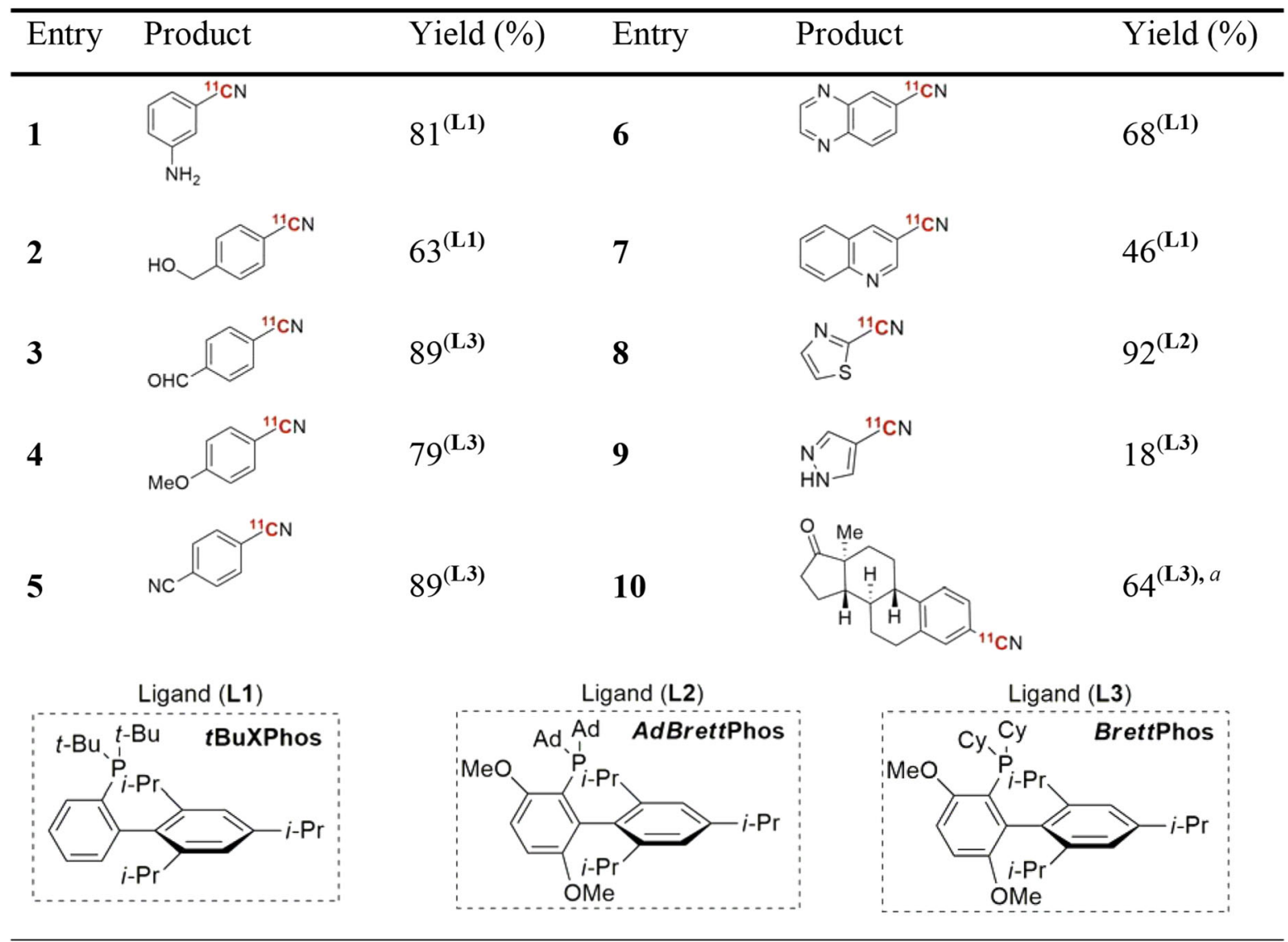

\footnotetext{
${ }^{a}$ Triflate substrate was used.
}

(pseudo)halides is well documented [74, 75]. A limitation of such reactions is that they require rather harsh conditions, such as high temperature, long reaction times, and inorganic bases (e.g. $\mathrm{KOH}$ ), which reduces the substrate scope. Recently, a novel method was reported describing near instantaneous, room temperature Pd-mediated coupling of $\left[{ }^{11} \mathrm{C}\right] \mathrm{HCN}$ to aryl halides or triflates [76]. The method is based on sterically hindered biaryl phosphine ligands (Table 4) that facilitate rapid transmetalation with $\left[{ }^{11} \mathrm{C}\right] \mathrm{HCN}$ and reductive elimination of aryl nitriles at ambient temperature. A wide variety of (hetero)arenes and drug-like molecules were radiolabeled in high yields, including the $\kappa$-opioid receptor radioligand $\left[{ }^{11}\right.$ C $]$ LY2795050 (Fig. 5). Moreover, two known antidepressants were also ${ }^{11} \mathrm{C}$-labeled in this study. This further illustrates the usefulness of the current method in the preparation of radiopharmaceuticals.
Carbon disulfide, the sulfur analogue of carbon dioxide, has recently been synthesized on-line from ${ }^{11} \mathrm{CH}_{3} \mathrm{I}$ using either $\mathrm{P}_{2} \mathrm{~S}_{5}$ and elemental sulfur $\left(\mathrm{S}_{8}\right)$ at elevated temperatures in excellent yields $[77,78]$. Due to the weaker $\mathrm{C}=\mathrm{S}$ bond $\mathrm{CS}_{2}$ is considered more reactive than $\mathrm{CO}_{2}$. Moreover, $\mathrm{CS}_{2}$ reacts very rapidly with many primary amines at room temperature to form the dithiocarbamate salts, which in turn, upon treatment with a suitable alkylating reagent will give the corresponding thiocarbamates. Heating, on the other hand, induces rearrangement to form the symmetrical thiourea (Scheme 7). Some model compounds were radiolabeled using this protocol in near quantitative yields. Finally, a progesterone receptor agonist, Tanaproget, was also produced in high RCY (Fig. 5).

Lastly, an improved, mild synthesis of $\left[{ }^{11} \mathrm{C}\right]$ formaldehyde have opened up new to carbon-11 labeled radiopharmaceuticals [79]. The treatment of trimethylamine $\mathrm{N}$-oxide 
Fig. 5 Radiopharmaceuticals labeled using either ${ }^{11} \mathrm{CN},{ }^{11} \mathrm{CS}_{2}$ and ${ }^{11} \mathrm{CH}_{2} \mathrm{O}$
Scheme $7{ }^{11} \mathrm{CS}_{2}$-fixation to form thioureas, thiocarbamates and thioisocyanate<smiles>N#Cc1ccc2[nH]cc(CCCCN3CCN(c4ccc5oc(C(N)=O)cc5c4)CC3)c2c1</smiles><smiles></smiles>

Gliotransmitter D-serine

Antidepessant<smiles>CNCCCC1(c2ccccc2)OCc2cc(C#N)ccc21</smiles>

$\left[{ }^{11} \mathrm{C}\right]$ citalopram Antidepessant<smiles>NC(=O)[14c]1ccc(Oc2ccc(CN3CCC(c4cccnc4)C3)cc2)c(Cl)c1</smiles>

$\left[{ }^{11} \mathrm{C}\right] \mathrm{LY} 2795050$ $\kappa$-opioid receptor radioligand
$5 \mathrm{HT}_{2 \mathrm{C}}$ receptor agonist radioligand<smiles>Cn1c(C#N)ccc1-c1ccc2c(c1)C(C)(C)OC(=S)N2</smiles>

$\left[{ }^{11} \mathrm{C}\right]$ Tanaproget Progesterone receptor radioligand

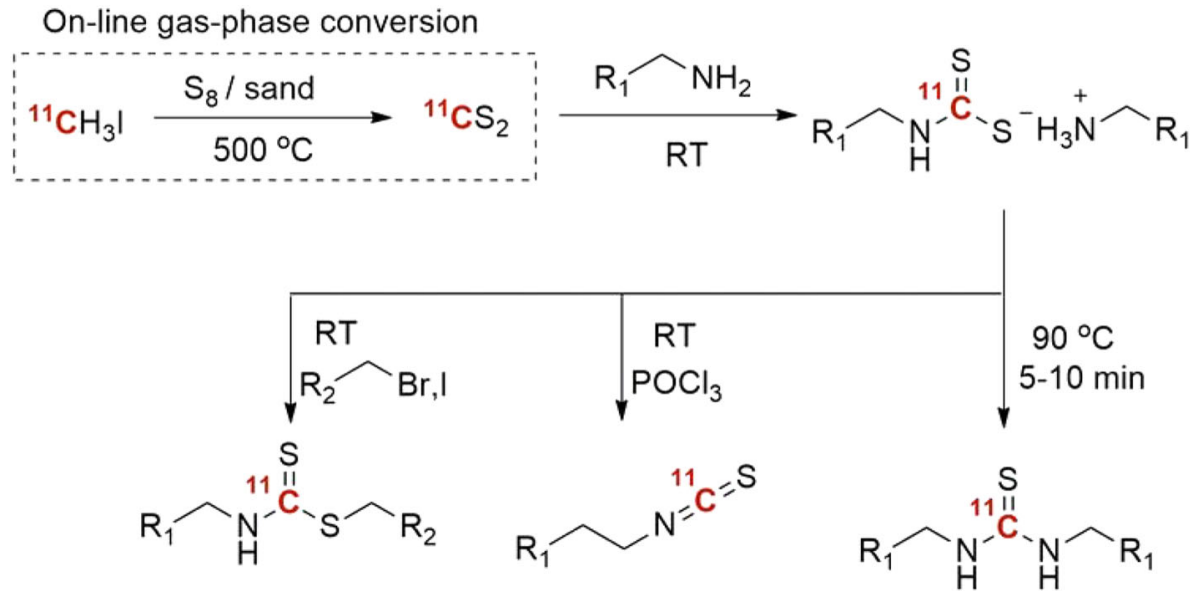

with ${ }^{11} \mathrm{CH}_{3} \mathrm{I}$ at room temperature gave ${ }^{11} \mathrm{CH}_{2} \mathrm{O}$ in a one-pot reaction. This novel preparation has been utilized by a number of groups to generate new exciting compounds (Fig. 5) [80, 81]. In addition, since $\left[{ }^{11} \mathrm{C}\right]$ formaldehyde was reported already in 1972 [82], there are other molecules previously reported in the literature that may now be synthesized in a simplified fashion using this protocol.

\section{Final remarks}

The increasing importance of PET in drug development and clinical research has motivated researchers to initiate programs directly dedicated to development of new radiolabeling methods. This review summarizes some of the most recent and promising strategies to obtain carbon- 11 
labeled products. In the past two decades, and well before this, efforts have brought to bear an impressive range of methods for ${ }^{11} \mathrm{C}$-radiochemistry. However, there are still issues to be addressed. Take for example, the heteroatom ${ }^{11} \mathrm{C}$-methylation reaction, which is now considered as an established method by the broader radiochemical community. Why is this? The main reason is the access to dedicated commercially available radiochemical equipment for this radiochemistry. Consequently, to streamline new methodologies, and make them widely available, new radiochemical equipment is needed. A possible approach to attack the problem could be to develop radiosynthesis equipment with a higher flexibility. A fundamental question is if microscale technology (microfluidic or microreactor) can provide a breakthrough in radiochemistry? Its compact design, flexible attributes, and its suitability for automation make microscale technology an ideal platform for performing the rapid radiolabeling reactions required for PET. So far, efforts made to adapt microscale technology for PET radiolabeling purposes have focused on proof-of-principle studies and to illustrate the advantages associated with the technology and significant further development is needed for the technology to reach its full potential. Although the authors recognize the importance of microreactor technologies, other technical approaches towards the development of more flexible radiochemical synthesis equipment are equally attractive at this point. Regardless of which direction is taken in the future, we firmly believe that a stronger collaboration between radiochemists and technical engineers is vital for succeeding in the development of the next generation of PET radiochemistry equipment.

Finally, radiochemistry is the foundation for PET imaging. By broadening the spectrum of radiochemical reactions within clinical PET radiochemistry, radiochemists will not only be able to increase the number of compounds that can be labeled with carbon-11 but also provide an increased opportunity to label a given compound in different positions.

Acknowledgements The authors thank members of the PET group at Karolinska Institutet.

\section{Compliance with ethical standards}

Conflict of interest KD declares that he has no conflict of interest. $\mathrm{CH}$ declares that he has no conflict of interest. MS declares the he is an employee and shareholder at AstraZeneca Pharmaceuticals.

Ethical approval This article does not contain any studies with human participants or animals performed by any of the authors. K Dahl: Literature Search and Review, Manuscript Writing. $\mathrm{C}$ Halldin: Content planning and Editing. M Schou: Content planning and Editing.
Open Access This article is distributed under the terms of the Creative Commons Attribution 4.0 International License (http://crea tivecommons.org/licenses/by/4.0/), which permits unrestricted use, distribution, and reproduction in any medium, provided you give appropriate credit to the original author(s) and the source, provide a link to the Creative Commons license, and indicate if changes were made.

\section{References}

1. Phelps ME (1991) PET: a biological imaging technique. Neurochem Res 16:929-940

2. Ametamey SM, Honer H, Schubiger PA (2008) Molecular imaging with PET. Chem Rev 108:1501-1516

3. Halldin C, Gulyas B, Langer O, Farde L (2001) Brain radioligands-state of the art and new trends. J Nucl Med 45:139-152

4. Pike VW (2009) PET radiotracers: crossing the blood-brain barrier and surviving metabolism. Trends Pharmacol Sci 30:431-440

5. Miller PW, Long NJ, Vilar R, Gee AD (2008) Synthesis of ${ }^{11} \mathrm{C}$, ${ }^{18} \mathrm{~F},{ }^{15} \mathrm{O}$, and ${ }^{13} \mathrm{~N}$ radiolabels for positron emission tomography. Angew Chem Int Ed 47:8998-9033

6. Pike VW (2016) Considerations in the development of reversibly binding PET radioligands for brain imaging. Curr Med Chem 23:1818-1869

7. Antoni G (2015) Development of carbon-11 labeled PET tracers-radiochemical and technological challenges in a historic perspective. J Label Compd Radiopharm 58:65-72

8. Scott P (2009) Methods for the incorporation of carbon-11 to generate radiopharmaceuticals for PET imaging. Angew Chem Int Ed 48:6001-6004

9. Långström B, Lundqvist H (1976) The preparation of ${ }^{11} \mathrm{C}$-methyl iodide and its use in the synthesis of ${ }^{11} \mathrm{C}$-methyl-L-methionine. Int Appl Radiat Isot 27:357-363

10. Larsen P, Ulin J, Dahlström K, Jensen M (1997) Synthesis of $\left[{ }^{11} \mathrm{C}\right]$ iodomethane by iodination of $\left[{ }^{11} \mathrm{C}\right]$ methane. Appl Radiat Isot 48:153-157

11. Jewett DM (1992) A simple synthesis of $\left[{ }^{11} \mathrm{C}\right]$ methyl triflate. Int Appl Radiat Isot 43:1383-1385

12. Någren K, Müller L, Halldin C, Swahn C, Lehikoinen P (1995) Improved synthesis of some commonly used PET radioligands by the use of $\left[{ }^{11} \mathrm{C}\right]$ methyl triflate. Nucl Med Biol 22:235-239

13. Pascali C, Bogni A, Iwata R, Cambie M, Bombardieri E (2000) $\left[{ }^{11} \mathrm{C}\right]$ Methylation on a $\mathrm{C}_{18}$ Sep-Pak cartridge: a convenient way to produce $\left[\mathrm{N}\right.$-methyl- $\left.{ }^{11} \mathrm{C}\right]$ choline. J Label Compd Radiopharm 43:195-203

14. Wilson AA, Garcia A, Jin L, Houle S (2000) Radiotracer synthesis from $\left[{ }^{11} \mathrm{C}\right]$-iodomethane: a remarkedly simple captive solvent method. Nucl Med Biol 27:529-532

15. Cai L, Xu R, Guo X, Pike VW (2012) Rapid room-temperature ${ }^{11} \mathrm{C}$-methylation of arylamines with $\left[{ }^{11} \mathrm{C}\right]$ methyl iodide promoted by solid inorganic-bases in DMF. Eur J Org Chem 1303-1310

16. Liger F, Eijsbouts T, Cadarossanesaib F, Tourvieille C, Le Bars $\mathrm{D}$, Billard $\mathrm{T}$ (2015) Direct $\left[{ }^{11} \mathrm{C}\right]$ methylation of amines from $\left[{ }^{11} \mathrm{C}_{\mathrm{CO}_{2}}\right.$ for the synthesis of PET radiotracers. Eur J Chem Org 6434-6438

17. Klunk W, Engler H, Norberg A, Wang Y, Blomqvist G, Holt D, Bergström M, Savitcheva I, Huang G, Estrada S, Ausén B, Debnath M, Baretta J, Price J, Sandell J, Lopresti B, Wall B, Koivisto P, Antoni G, Mathis CA, Långström B (2004) Imaging brain amyloid in Alzheimer's disease with Pittsburgh compoundB. Ann Neurol 55:306-319 
18. Pretze M, Große-Gehling P, Mamat C (2011) Cross-coupling as a versatile tool for the preparation of PET radiotracers. Molecules 16:1129-1165

19. Doi H (2015) Pd-mediated cross-couplings using $\left[{ }^{11} \mathrm{C}\right]$ methyl iodide: groundbreaking labeling methods in ${ }^{11} \mathrm{C}$ radiochemistry. J Label Compd Radiopharm 58:73-85

20. Tarkiainen J, Vercouillie J, Emond P, Sandell J, Hiltunen J, Frangin Y, Guilloteau D, Halldin C (2001) Carbon-11 labeling of MADAM in two different positions: a highly selective PET radioligand for the serotonin transporter. J Label Compd Radiopharm 44:1013-1023

21. Sandell J, Halldin C, Sovago J, Chow Y, Gulyás B, Yu M, Emond P, Någren K, Guilloteau D, Farde L (2002) PET examination of $\left[{ }^{11} \mathrm{C}\right] 5$-methyl-6-nitroquipazine, a radioligand for visualization of the serotonin transporter. Nucl Med Biol 29:651-656

22. Karimi F, Långström B (2002) Synthesis of 3-[(2S)-azetidin-2ylmethoxy $]-5-\left[{ }^{11} \mathrm{C}\right]-$ methylpyridine, an analogue of A-85380, via a Stille coupling. J Label Compd Radiopharm 45:423-434

23. Iida Y, Ogawa M, Ueda M, Tominaga A, Kawashima H, Magata Y, Nishiyama S, Tsukada H, Mukai T, Saji H (2004) Evaluation of $5-{ }^{11}$ C-Methyl-A-85380 as an imaging agent for PET investigations of brain nicotinic acetylcholine receptors. J Nucl Med 45:878-884

24. Paterson D, Nordberg A (2000) Neuronal nicotinic receptors in the human brain. Prog Neurobiol 61:75-111

25. Björkman M, Doi H, Resul B, Suzuki M, Noyori R, Watanabe Y, Långström B (2000) Synthesis of a ${ }^{11} \mathrm{C}$-labeled prostaglandin $\mathrm{F}_{2 \alpha}$ analogue using an improved method for the Stille reaction with $\left[{ }^{11} \mathrm{C}\right]$ methyl iodide. J Label Compd Radiopharm 43:1327-1334

26. Suzuki M, Doide H, Hosoya T, Långström B, Watanabe (2004) Rapid methylation on carbon frameworks leading to the synthesis of a PET tracer capable of imaging a novel CNS-type prostacyclin receptor in living human brain. TrAC Trends Anal Chem 23:595-607

27. Takashima T, Kitamura S, Wada Y, Tanaka M, Shigihara Y, Ishii H, Ijuin R, Shiomi S, Nakae T, Watanabe Y, Cui Y, Doi H, Suzuki M, Maeda K, Kusuhara H, Sugiyama Y, Watanabe Y (2012) PET imaging-based evaluation of hepatobiliary transport in humans with $(15 R)-{ }^{11} \mathrm{C}$-TIC-Me. J Nucl Med 53:741-748

28. Kealey S, Passchier J, Huiban M (2013) Negishi coupling reactions as a valuable tool for $\left[{ }^{11} \mathrm{C}\right]$ methyl-arene formation; first proof of principle. Chem Comm 49:11326-11328

29. Hamill T, Krause S, Ryan C, Bonnefous C, Govek S, Seiders J, Gibson R, Sanabria S, Riffel K, Eng W, King C, Yang X, Green M, O’Malley S, Hargreaves R, Burns D (2005) Synthesis, characterization, and first successful monkey imaging studies of metabortropic glutamate receptor subtype 5 (mGluR5) PET radiotracer. Synapse 56:205-216

30. Takashima-Hirano M, Shukuri M, Takashima T, Goto M, Wada Y, Watanabe Y, Onoe H, Doi H, Suzuki M (2010) General method for the ${ }^{11} \mathrm{C}$-labeling of 2-arylpropionic acids and their esters: construction of a PET tracer library for a study of biological events involved in COXs expression. Chem Eur J $16: 4250-4258$

31. Kato K, Kikuchi T, Nengaki N, Arai T, Zhang M (2010) Tetrabutylammonium fluoride-promoted $\alpha-\left[{ }^{11} \mathrm{C}\right]$ methylation of $\alpha$-arylesters: a simple and robust method for the preparation of ibuprofen. Tetrahedron Lett 51:5908-5911

32. Filp U, Pekošak A, Poot A, Windhorst B (2016) Enantioselective synthesis of carbon-11 labeled L-alanine using phase transfer catalysis of Schiff bases. Tetrahedron 72:6551-6557

33. Dahl K, Schou M, Halldin C (2016) Direct and efficient (carbonyl) cobalt-mediated aryl acetylation using $\left[{ }^{11} \mathrm{C}\right]$ methyl iodide. Eur J Org Chem 2775-2777
34. Hooker JM, Reibel A, Hill S, Schueller M, Fowler JS (2009) One-pot, direct incorporation of $\left[{ }^{11} \mathrm{C}_{\mathrm{CO}_{2}}\right.$ into carbamates. Angew Chem Int Ed 48:3482-3485

35. Wilson A, Garcia A, Houle S, Vasdev N (2010) Direct fixation of $\left[{ }^{11} \mathrm{C}\right]-\mathrm{CO}_{2}$ by amines: formation of $\left[{ }^{11} \mathrm{C}\right.$-carbonyl $]$-methylcarbamates. Org Biomol Chem 8:428-432

36. Rotstein B, Liang S, Placzek M, Hooker JM, Gee AD, Dollé F, Wilson A, Vasdev N (2016) ${ }^{11}$ CO bond made easily for positron emission tomography radiopharmaceuticals. Chem Soc Rev 45:4708-4726

37. Rotstein B, Liang S, Holland J, Lee TL, Hooker JM, Wilson A, Vasdev N (2013) ${ }^{11} \mathrm{CO}_{2}$ fixation: a renaissance in PET radiochemistry. Chem Comm 49:5621-5629

38. Wilson A, Garcia A, Houle S, Sadovski O, Vasdev N (2011) Synthesis and application of isocyanates radiolabeled with carbon-11. Chem Eur J 17:259-264

39. Vasdev N, Garcia A, Stableford W, Young A, Meyer J, Houle S, Wilson AA (2005) Synthesis an ex vivo evaluation of carbon-11 labeled $\quad N$-(4-methoxybenzyl)- $N^{\prime}$-(5-Nitro-1,3-thiazol-2-yl)urea ( $\left.\left[{ }^{11} \mathrm{C}\right] \mathrm{AR}-\mathrm{A} 014418\right)$ : a radiolabeled glycogen synthase kinase- $3 \beta$ specific inhibitor for PET studies. Bioorg Med Chem Lett 15:5270-5273

40. Hicks J, Parkes J, Sadovski O, Tong J, Houle S, Vasdev N, Wilson A (2012) Synthesis and preclinical evaluation of $\left[{ }^{11} \mathrm{C}\right.$ carbonyl]PF-04457845 for neuroimaging of fatty acid amide hydrolase. Nucl Med Biol 40:740-746

41. Hicks J, Parkes J, Sadovski O, Tong J, Houle S, Vasdev N, Wilson A (2012) Synthesis and preclinical evaluation of $\left[{ }^{11} \mathrm{C}\right.$ carbonyl]PF-04457845 for neuroimaging of fatty acid amide hydrolase. Nucl Med Biol 40:740-746

42. Wilson AA, Hicks J, Sadovski O, Parkes J, Tong J, Houle S, Fowler C, Vasdev N (2013) Radiosynthesis and evaluation of $\left[{ }^{11} \mathrm{C}\right.$-carbonyl]-labeled carbamates as fatty acid amide hydrolase radiotracer for positron emission tomography. J Med Chem $56: 201-209$

43. Boileau I, Rusjan P, Williams B, Mansouri E, Mizrahi R, De Luca V, Johnson D, Wilson AA, Houle S, Kish S, Tong J (2015) The fatty acid amide C385A variant affects brain binding of the positron emission tomography tracer $\left[{ }^{11} \mathrm{C}\right] \mathrm{CURB}$. J Cereb Blood Flow Metab 35:1827-1835

44. Vasdev N, Sadovski O, Garcia A, Dollé F, Meyer J, Houle S, Wilson A (2011) Radiosynthesis of $\left[{ }^{11} \mathrm{C}\right] \mathrm{SL} 25.1188$ via $\left[{ }^{11} \mathrm{C}\right] \mathrm{CO}_{2}$ fixation for imaging of monoamine oxidase B. J Label Compd Radiopharm 54:678-680

45. Saba W, Valette H, Peyronnea M, Bramoulle Y, Coulon C, Curet O, George P, Dolle F, Bottlaender M (2010) $\left[{ }^{11} \mathrm{C}\right]$ SL25.1188, a new reversible radioligand to study the monoamine oxidase type B with PET: preclinical characterization in nonhuman primate. Synapse 64:61-69

46. Rusjan P, Wilson AA, Miler L, Fan I, Mizrahi R, Houle S, Vasdev N, Meyer J (2014) Kinetic modeling of the monoamine oxidase B radioligand $\left[{ }^{11} \mathrm{C}\right] \mathrm{SL} 25.1188$ in human brain imaging with positron emission tomography. J Cereb Blood Flow Metab 34:883-889

47. Dheere A, Yusuf N, Gee AD (2013) Rapid and efficient synthesis of $\left[{ }^{11} \mathrm{C}\right]$ ureas via incorporation of $\left[{ }^{11} \mathrm{C}\right] \mathrm{CO}_{2}$ into aliphatic and aromatic amines. Chem Comm 49:8193-8195

48. Dheere A, Bongarzone S, Taddei C, Yan R, Gee AD (2015) Synthesis of ${ }^{11} \mathrm{C}$-labeled symmetrical ureas via rapid incorporation of $\left[{ }^{11} \mathrm{C}_{\mathrm{CO}_{2}}\right.$ into aliphatic and aromatic amines. Synlett 26:2257-2260

49. Riss P, Lu S, Telu S, Aigbirhio F, Pike VW (2012) $\mathrm{Cu}^{\mathrm{I}}$-catalyzed ${ }^{11} \mathrm{C}$ carboxylation of boronic acid esters: a rapid and convenient entry to ${ }^{11} \mathrm{C}$-labeled carboxylic acids, esters, and amides. Angew Chem Int Ed 51:2698-2702 
50. Rotstein B, Hooker JM, Woo J, Lee TL, Brady T, Liang S, Vasdev N (2014) Synthesis of $\left[{ }^{11} \mathrm{C}\right]$ bexarotene by $\mathrm{Cu}$-mediated $\left[{ }^{11} \mathrm{C}\right]$ carbon dioxide fixation and preliminary PET imaging. ACS Med Chem Lett 5:668-672

51. Zeisler SK, Nader M, Oberdorfer F (1997) Conversion of nocarrier-added $\left[{ }^{11} \mathrm{C}\right]$ carbon dioxide to $\left[{ }^{11} \mathrm{C}\right]$ carbon monoxide on molybdenum for the synthesis of ${ }^{11} \mathrm{C}$-labeled aromatic ketones. Appl Radiat Isot 48:1091-1095

52. Dahl K, Itsenko O, Rahman O, Ulin J, Sjöberg C, Sandblom P, Larsson L, Schou M, Halldin C (2015) An evaluation of a highpressure ${ }^{11} \mathrm{CO}$ carbonylation apparatus. J Labell Compd Radiopharm 58:220-225

53. Brennführer A, Neumann H, Beller M (2009) Palladium-catalyzed carbonylation reactions of aryl halides and related compounds. Angew Chem Int Ed 48:4114-4133

54. Långström B, Itsenko O, Rahman $\mathrm{O}$ (2007) $\left[{ }^{11} \mathrm{C}\right]$ carbon monoxide, a versatile and useful precursor in labelling chemistry for PET-ligand development. J Labell Compd Radiopharm 50:794-810

55. Kealey S, Gee AD, Miller PW (2014) Transition metal mediated $\left[{ }^{11} \mathrm{C}\right]$ carbonylation reactions: recent advances and applications. J Labell Compd Radiopharm 57:195-201

56. Rahman O (2015) $\left[{ }^{11} \mathrm{C}\right]$ Carbon monoxide in labeling chemistry and positron emission tomography tracer development: scope and limitations. J Labell Compd Radiopharm 58:86-98

57. Andersson Y, Långström B (1995) Synthesis of ${ }^{11} \mathrm{C}$-labeled ketones via carbonylative couplings reaction using $\left[{ }^{11} \mathrm{C}\right]$ carbon monoxide. J Chem Soc Perkin Trans 1:287-289

58. Lidström P, Kihlberg T, Långström B (1997) $\left[{ }^{11} \mathrm{C}\right]$ carbon monoxide in the palladium-mediated synthesis of ${ }^{11} \mathrm{C}$-labeled ketones. J Chem Soc Perkin Trans 1:2701-2706

59. Kealey S, Miller PW, Long N, Plisson C, Martarello L, Gee AD (2009) Copper(I) scorpionate complexes and their application in palladium-mediated $\left[{ }^{11} \mathrm{C}\right]$ carbonylation reactions. Chem Comm 25:3696-3698

60. Dahl K, Schou M, Ulin J, Sjöberg C, Farde L, Halldin C (2015) ${ }^{11} \mathrm{C}$-Carbonylation reaction using gas-liquid segmented microfluidics. RSC Adv 5:88886-88889

61. Kihlberg T, Långström B (1999) Biologically active amides using palladium-mediated reactions with aryl halide and $\left[{ }^{11} \mathrm{C}\right]$ carbon monoxide. J Org Chem 64:9201-9205

62. Eriksson J, van den Hoek J, Windhorst AD (2012) Transition metal mediated synthesis using $\left[{ }^{11} \mathrm{C}\right] \mathrm{CO}$ at low pressure-a simplified method for ${ }^{11} \mathrm{C}$-carbonylation. J Labell Compd Radiopharm 55:223-228

63. van der Wildt B, Wilhelmus M, Bijkerk J, Haveman L, Kooijman E, Schuit R, Bol J, Jongenelen C, Lammertsma A, Drukarch B, Windhorst AD (2016) Development of carbon-11 labeled acryl amides for selective PET imaging of active tissue transglutaminase. Nucl Med Biol 43:232-242

64. Stevens M, Chow S, Estrada S, Eriksson J, Asplund V, Orlova A, Mitran B, Antoni G, Larhed M, Odell L (2016) Synthesis of ${ }^{11} \mathrm{C}$ labeled sulfonyl carbamates through a multicomponent reaction employing sulfonyl azides, alcohols, and $\left[{ }^{11} \mathrm{C}\right] \mathrm{CO}$. ChemistryOpen 5:566-573

65. Chow S, Odell L, Eriksson J (2016) Low-pressure radical ${ }^{11} \mathrm{C}$ aminocarbonylation of alkyl iodides through thermal initiation. Eur J Org Chem 5980-5989
66. Dahl K, Schou M, Amini N, Halldin C (2013) Palladium-mediated $\left[{ }^{11} \mathrm{C}\right]$ carbonylation at atmospheric pressure: a general method using xantphos as supporting ligand. Eur J Org Chem $1228-1231$

67. Dahl K, Schou M, Rahman O, Halldin C (2014) Improved yields for the palladium-mediated ${ }^{11} \mathrm{C}$-carbonylation reaction using microwave technology. Eur J Org Chem 307-310

68. Rahman O, Takano A, Amini N, Dahl K, Kanegawa N, Långström B, Farde L, Halldin C (2015) Synthesis of $\left(\left[{ }^{11} \mathrm{C}\right]\right.$ carbonyl)raclopride and a comparison with $\left(\left[{ }^{11} \mathrm{C}\right]\right.$ methyl) raclopride in a monkey PET study. Nucl Med Biol 11:893-898

69. Andersen T, Friis S, Audrain H, Nordeman P, Antoni G, Skrydstrup T (2015) Efficient ${ }^{11} \mathrm{C}$-carbonylation of isolated aryl palladium complexes for PET: application to challenging radiopharmaceutical synthesis. J Am Chem Soc 137:1548-1555

70. Rahman O, Långström B, Halldin C (2016) Alkyl halides and $\left[{ }^{11} \mathrm{C}\right] \mathrm{CO}$ in nickel-mediated cross-coupling reactions: successful use of alkyl electrophiles containing $\beta$ hydrogen atom in metalmediated $\left[{ }^{11} \mathrm{C}\right]$ carbonylation. ChemistrySelect 1:2498-2501

71. Matsson $\mathrm{O}$, Persson $\mathrm{J}$, Axelsson BS, Långström $\mathrm{B}$, Fang $\mathrm{A}$, Westaway KC (1996) Using incoming group ${ }^{11} \mathrm{C} /{ }^{14} \mathrm{C}$ kinetic isotope effects to model the transition states for the $\mathrm{S}_{\mathrm{N}} 2$ reaction between para-substituted benzyl chloride and labeled cyanide ion. J Am Chem Soc 118:6350-6354

72. Antoni $\mathrm{G}$, Långström $\mathrm{B}$ (1992) Synthesis of 11C-labeled $\alpha, \beta$ saturated nitriles. Int Appl Radiat Isot 43:903-905

73. Thorell J, Stone-Elander S, Elander N (1992) Use of microwave cavity to reduce reaction times in radiolabelling with $\left[{ }^{11} \mathrm{C}\right]-$ cyanide. J Labell Compd Radiopharm 31:207-217

74. Andersson Y, Långström B (1995) Transition metal-mediated reactions using $\left[{ }^{11} \mathrm{C}\right]$ cyanide in synthesis of ${ }^{11} \mathrm{C}$-labeled aromatic compounds. J Chem Soc Perkin Trans 1:1395-1400

75. Ponchant M, Hinnen F, Demphel S, Crouzel C (1997) ${ }^{11-}$ C]Copper(I) cyanide: a new radioactive precursor for ${ }^{11} \mathrm{C}$-cyanation and functionalization of haloarenes. Appl Radiat Isot 48:755-762

76. Lee HG, Milner P, Placzek M, Buchwald SL, Hooker JM (2015) Virtually instantaneous, room-temperature $\left[{ }^{11} \mathrm{C}\right]$-cyanation using biaryl phosphine Pd(0) complexes. J Am Chem Soc 137:648-651

77. Miller PW, Bender D (2012) $\left[{ }^{11} \mathrm{C}\right]$ Carbon disulfide: a versatile reagent for PET radiolabelling. Chem Eur J 18:433-436

78. Haywood T, Kealey S, Sánchez-Cabezas S, Hall J, Allott L, Smith G, Plisson C, Miller PW (2015) Carbon-11 radiolabelling of organosulfur compounds: ${ }^{11} \mathrm{C}$ synthesis of the progesterone receptor agonist tanaproget. Chem Eur J 21:9034-9038

79. Hooker JM, Schönberger M, Schieferstein H, Fowler J (2008) A simple, rapid method for the preparation of $\left[{ }^{11} \mathrm{C}\right]$ formaldehyde. Angew Chem Int Ed 47:5989-5992

80. Popkov A, Itsenko O (2015) An asymmetric approach to the synthesis of a carbon-11 labeled gliotransmitter D-serine. J Radioanal Nucl Chem 304:455-458

81. Neelamegam R, Hellenbrand T, Schroeder F, Wang C, Hooker $\mathrm{JM}$ (2014) Imaging evaluation of $5 \mathrm{HT}_{2 \mathrm{C}}$ agonist, $\left[{ }^{11} \mathrm{C}\right] \mathrm{WAY}-$ 163909 and $\left[{ }^{11} \mathrm{C}\right]$ vabicaserin, formed by Pictet-Spengler cyclization. J Med Chem 57:1488-1494

82. Christman D, Crawford E, Friedkin M, Wolf AP (1972) Detection of DNA synthesis in intact organisms with positron-emission [methyl- ${ }^{11}$ C] thymidine. Proc Natl Acad Sci 69:988-992 